\title{
All Aboard the Desistance Line: First Stop, Producing Prosocial Prison Attachments within an HIV Prison-Based Peer Program
}

\author{
by KIMBERLY COLLICA-COX \\ Pace University
}

\begin{abstract}
This article explores the importance of social bonds in facilitating an investment in prosocial behavior amongst female prisoners working as HIV peer educators. Female prisoners can lack strong prosocial attachments to both individuals and institutions prior to incarceration. Absent this bond, little prevents the female prisoner from recidivating. Prison provides an opportunity to fashion new attachments that will assist in the reintegrative process. One way to create strong bonds of attachment, particularly for women, is through working as an HIV peer educator while incarcerated. In order to measure attachment levels, interviews were conducted with 49 female prisoners who worked in two HIV prison-based peer programs during their incarceration. Female peers developed strong attachments to one another. Such attachments were formed while incarcerated and were maintained upon release, thus serving to bolster support for newfound prosocial identities.
\end{abstract}

Key words: HIV Peer Programs; Attachment; Female Prisoners, Prosocial Identity

Individuals are likely to commit crime when prosocial bonds are deficient or damaged (Hirschi, 1969), encumbering one's departure from criminal behavior. When female prisoners lack strong prosocial attachments to both individuals and institutions prior to incarceration, little prevents them from recidivating. Although this is not always the case, bonds established before incarceration can weaken during a prisoner's time away, and the longer one is incarcerated, the more likely these bonds will further deteriorate (Petersilia, 2006). If social bonds are cultivated before a prisoner's release, she has a greater chance of maintaining a crime-free lifestyle (Hepburn \& Griffin, 2004; Uggen, 2000). "A particularly prominent body of literature [suggests] social bonds play a central role in the reentry process" (Rocque, Bierie, Posick, \& Mackenzie, 2013, p. 210). Strong social networks and a high level of "social capital" are essential for successful reintegration for female prisoners (Reisig, Holtfreter, \& Morash, 2002). Although rarely acknowledged, prison can provide an opportunity to construct new social capital that assists in the reintegrative process, even when the newly formed relationships are fostered with fellow transgressors. Prison-based programs, which typically promote prosocial behavior, can connect prisoners to other prisoners who also want to invest in a prosocial (i.e., crimefree) lifestyle. These programs can assist prisoners in the desistance process by creating an environment that promotes prosocial behavior, in addition to showing them how to serve as a source of support for one another in their new prosocial roles (Koons, Burrow, Morash, \& Bynum, 1997).

This study investigates whether prosocial bonds between prisoners develop within the correctional setting by examining two non-traditional prison-based vocational programs for female offenders in New York State (NYS) - the ACE (AIDS, Counseling \& Education) Program at Bedford Hills Correctional Facility (BHCF) and the CARE (Counseling, AIDS, Resource and Education) Program at Taconic Correctional Facility (TCF); both programs are centered upon HIV peer education. There is little research conducted on less traditional vocational opportunities behind bars, such as HIV/AIDS peer education programs, and there is a paucity of literature regarding whether prosocial bonds develop when working in prison-based programs.

Correspondence: Kimberly Collica-Cox, Email: kcollicacox@pace.edu

(Accepted: 9/12/16) ISSN: 2387-2306 doi: http://dx.doi.org/10.15845/jper.v3i1.1001

Except where otherwise noted, content on this site is licensed under a Creative Commons Attribution 4.0 International License.

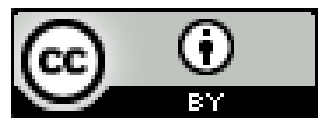




\section{Literature Review}

\section{U.S. Incarceration}

Approximately two million people are incarcerated in prisons; upon release, $67 \%$ of prisoners will return within a three year period (Durose, Cooper \& Sydner, 2014). Mass incarceration is an American endeavor that began in the 1980s with the War on Drugs, disproportionately affecting poor persons and persons of color, often for non-violent crimes (Amnesty International, 2016). Women are not immune from these statistics. In a 2006 secondary data analysis of the Bureau of Justice Statistics' (BJS) recidivism data, 60\% of female offenders were rearrested after release, $40 \%$ had new convictions and 30\% returned to prison (Deschenes, Owen, \& Crow, 2006). Overall, women prisoners present with more needs than their male counterparts, experiencing higher rates of depression, self-destructive behavior, and other types of mental illness (Jasperson, 2010; Keaveny \& Zauszniewski; 1999). Powerlessness and dependency upon the normative structure of the prison can provide additional hindrances to the rehabilitative and reintegrative success for the female prisoner (Boudin, 1993). With only five percent of the world's population, the U.S. holds $22 \%$ of its prisoners, which is further complicated by the fact that as incarceration costs increase, funding for prison-based programming substantially decreases (Amnesty International, 2016). With this in mind, utilizing limited funds for programs that are evidence-based is more important than ever before.

\section{HIV \& Prison}

Although rates of HIV infection and AIDS-related deaths are in decline (Maruschak, 2015), HIV is still a major health risk for prisoners, with the rate of infection among incarcerated populations five times greater than the rate within the general community (CDC, 2016). In the beginning of the AIDS epidemic, the curiosity of prisoners about AIDS was used to help promote literacy efforts for women at BHCF (Bedford Hills Correctional Facility); prisoners were able to discuss and write about AIDS, a subject which was of great concern (Boudin, 1993). Their interest led to a play about AIDS' issues, which eventually led to the creation of the ACE Program (Boudin, 1993).

BHCF is the only maximum-security prison for women in NYS, holding approximately 800 prisoners. Taconic Correctional Facility (TCF), located across the street from BHCF, is a medium-security facility for women in NYS, holding approximately 400 prisoners ${ }^{1}$. Both ACE and CARE, in existence since the late 1980 s, were created to provide a variety of services to the incarcerated population such as support groups, education, crisis counseling, HIV testing, discharge planning, special events, professional trainings, etc. ACE peers worked in hospice (also referred to as IPC - In Patient Care) to comfort and assist prisoners who were dying from AIDS-related complications during the height of the epidemic.

The high number of AIDS related deaths among prisoners in the 1990s (in addition to the use of longer sentencing options) led to an increase in prison hospice programs (Thigpen \& Hunter, 1998). With AIDS related deaths in decline, hospice availability is still vital to the prison because of its aging prison population (a direct result of longer sentencing). Research shows that at least five elements are needed for successful prison-based hospice care: "patient-centered care, an inmate volunteer model, safety and security, shared values, and teamwork" (Cloyes, Rosenkranz, Berry, Supiano, Routt, Shannon-Dorcy, \& Llanque, 2016, p. 390). When compared to community-based services, prison hospice is much stricter in regard to its volunteers, who are typically other prisoners (Hoffman \& Dickinson, 2011). For NYS women prisoners, hospice programming is available at BHCF, and ACE peers were permitted to work with HIV patients when little was known about transmission and when death was often within six months of diagnosis (ACE, 1998). ACE successfully used a prisoner volunteer model at the program's onset, and the women of ACE continue to help prisoners struggling with terminal illnesses. Studies find that prisoners who work/volunteer in hospice undergo positive changes in self-perception; the experience can be transformative (Cloyes, Rosenkranz, Wold, Berry, \& Supiano, 2014).

\section{Attachment}

A continued commitment to positive change will require support from those who seek and maintain attachment bonds. "Attachment" refers to the emotional closeness one shares with family, peers and institutions

\footnotetext{
${ }^{1}$ These numbers hold true at the time of data collection. The population for New York State, like most states, has decreased considerably.
} 
(i.e., school, place of employment or religious establishment) (Chriss, 2007). Researchers argue that when we attach to other individuals or institutions (those that promote prosocial behavior, specifically anti-criminal involvements and behavior), we are more likely to believe in prosocial rules (i.e. adherence to the penal law) and there is a greater desire to engage in prosocial behavior; this involves an investment in obtaining employment, attaining housing, and circumventing criminal associates or behavior (Chriss, 2007). In regard to prisoners, a prosocial identity means replacing one's criminal identity with a law-abiding identity; it relates to one who is ready to abandon criminal ideas, motivations, and rationalizations. These prosocial scripts can inspire prisoners to take a strengths-based approach, focusing on how they can contribute to their communities by identifying their positive attributes, which, in turn, helps them to achieve a sense of worth and value, both of which are important in maintaining a crime-free identity (Maruna \& LeBel, 2003). Attachment damage, which often begins in adolescence as a result of delinquency or criminal involvement, affects the quality and strength of attachments in adulthood, increasing the possibility for adult offending (Chapple, Hope, \& Whiteford, 2005; Cretacco, Fei Ding, \& Rivera, 2010; Intravia, Jones \& Piquero, 2012).

Engaging in criminal activity can destroy relationships between persons when one has a commitment to maintaining a prosocial identity; therefore, the fear of damaging these relationships helps to promote prosocial behavior. Nonetheless, it is important to remember that there are both positive and negative attachments (Belknap, 2015). Not all attachments are beneficial and criminal attachments can promote unlawful behavior (Burton, 1991; Hindelang, 1973; Sutherland, 1949). Even when strong attachments develop, it does not necessarily preclude future criminality (Rankin, 1976). In fact, there are instances where "seemingly" positive attachments exist with other persons engaged in prosocial behaviors that have no effect on criminal behavior (Terry \& Freilich, 2012). It is not solely the bonds to society that serve to modify; it is their quality and strength. Those with an investment in maintaining a prosocial identity have reduced recidivism (Piquero, 2003) and those with strong attachments to others who are also invested in maintaining a prosocial identity are less likely to recidivate (MacKenzie \& De Li, 2002; Rocque et al., 2013).

Most of the literature regarding the social bonding process for prisoners focuses on processes occurring after the prisoner's release (Laub \& Sampson, 2003; Lopoo \& Western, 2005). However, during the incarceration process, relationships, established prior to prison, can change for the worse. The stigmatization of incarceration and the negative labels that ensue can make it difficult for prisoners to establish new bonds (Laub \& Sampson, 2003). The prison experience creates obstacles to maintaining old bonds, while the negative label of "criminal" makes it difficult to attach to prosocial institutions and to create new prosocial partnerships upon release (Graffam, Shinkfield, \& Hardcastle, 2008; Huebner, 2007; Shinkfield \& Graffam, 2009; Western, 2002).

\section{Attachment for Girls and Women}

Males and females are affected differently in regard to pathways toward, and desistance from, crime; a gender-specific understanding of pathways to crime and desistance is needed (Booth, Farrell, \& Varano, 2008). Initial studies regarding social bonds and their relationship to delinquency focus exclusively on males (Belknap, 2015). Subsequent studies shed some light on its applicability to women, but findings are not unequivocal. Strong family relationships appear particularly important in controlling deviant behavior amongst adolescence girls (Belknap, 2015; Sepsi, 1974). For adults, much of the literature on attachment points to the marital bond as an aid in the desistance process (Sampson \& Laub, 1993; Wyse, Harding, \& Morenoff, 2014). Yet, marital bonds shape male and female behavior differently (Li \& MacKenzie, 2003) and while marriage appears to enable the desistance process for men, the research on women, marriage and desistance is not as clear (Alarid, Burton, \& Cullen, 2000; Cobbina, Huebner, \& Berg, 2012; Thompson \& Petrovic, 2009). Relationships that occur after a woman's release from prison tend to involve partners with similar criminal or addictive histories; women's relationships with men involved in crime lead to women returning to crime (Bersani, Laub, \& Nieuwbeerta, 2009; Wyse et al., 2014). Marriage does not seem to have a strong effect on the formerly incarcerated woman's drug use or her level of criminal activity (O'Connell, 2003). Women leaving prison may not have the same opportunities as men to partner with spouses who engage in prosocial activities, and criminal partners are more likely to predict recidivism for women than men (Benda, 2005). It appears that marriage itself is not necessarily life altering for women; it must be with a spouse who is invested 
in maintaining a prosocial identity in order to have any discernible effect on criminality.

Even while incarcerated, women are less likely than incarcerated men to have a supportive spouse, and they are more likely than their male counterparts to be responsible for child care, reunification issues and displaced children upon release (Dodge \& Pogrebin, 2014). The quality of relationships, especially with family members, assists in promoting reintegration and helps to insulate women from behavior that results in re-arrest (Bahr, Armstrong, Gibbs, Harris \& Fisher, 2005; Valera, Chang, Hernandez, \& Cooper, 2015). Regrettably, successful reintegration is often hindered for female offenders because establishing successful and prosocial relational bonds is difficult. Even if women have strong bonds prior to incarceration, the distance and cost of maintaining contact with family members makes it difficult to remain in consistent contact and can inevitably weaken previously established relationships (Petersilia, 2006). Visitation with family and friends while incarcerated can promote the bond of attachment and reduce offending (Bales \& Mears, 2008), but incarcerated women tend to receive fewer visits than men. Many women who come to prison suffer with attachment issues as a result of past trauma, broken families, abuse, neglect and psychopathologies (Belknap, 1996; Dow, 2001). Although social bonds are a vital component to reentry success, behavioral change and reduced recidivism (Bersani, et al., 2009; Laub \& Sampson, 2003; Sampson, Laub \& Wimer, 2006), especially at the time of release (Hepburn \& Griffin, 2004; O’Connell, 2003; Piquero, 2003; Tripodi, 2010; Uggen, 2000), women are at a clear disadvantage. Yet, women, when compared to men, appear to need and have more social support from one another while incarcerated (Jiang \& Winfree, 2006). The importance of having peer support in prison cannot be underestimated (Toch, 1975), especially for the woman who lacks social support outside of the prison environment. Strong social supportive networks not only assist with prison adaptation, but they aid in the reintegrative process (Cullen, 1994; Reisig et al., 2002). Strong social support, particularly through programming, can reduce the harmful effects of prison (Colvin, Cullen \& Vander Ven, 2002), such as mediating feelings of hostility among releasees (Hochstetler, DeLisi, \& Pratt, 2010). Empirical relationships are found between the development and maintenance of social bonds during incarceration and the subsequent risk for recidivism (Rocque et al., 2013). "It is fitting that social support [is] also linked to recidivism, desistance, and reintegration among correctional or high criminality samples" (Hochstetler et al., 2010, p. 591).

With limited prosocial attachments available, it is necessary to examine whether attachments for women prisoners can be created while incarcerated and maintained upon release to promote successful reintegration. Risk factors (i.e., separation from children, low self-esteem, prior abuse, mental illness, etc) for maladaptive behavior can be gender-specific (Celinska \& Sung, 2014; Jiang \& Winfree, 2006; Wright, Salisbury, \& Van Voorhis, 2007). Prison can make a difference in the offenders' lives by allowing bonds to be created or reintroduced (Rocque at. al., 2013), but prison can also limit the success of the desistance process by damaging bonds (Petersilia, 2003) (i.e., when factoring the costs of time, distance and finances, bonds are difficult for family members to maintain with incarcerated loved ones). Disappointingly, research often ignores the social bonding processes in prison, focusing exclusively on postrelease attachments (Rocque at. al., 2013).

The bonds created between women prisoners while incarcerated can play a role in institutional adjustment. Prison adaptation is of great concern for prison administrators as the way one adapts to the prison environment can negatively impact behavior and lead to increased disciplinary problems; maladaptive behaviors are also likely to impede reintegration (Clemmer 1940; Irwin \& Cressey, 1962). Female prisoners may bond with one another through the recreation of family units (i.e., pseudo families) inside prison walls (Giallombardo, 1966.) Family creation could serve as a coping mechanism to ameliorate the pains associated with incarceration (i.e., the separation from one's family and children), and they appear to be primary in meeting and fulfilling the emotional needs of the female prisoner (DeBell, 2001; Huggins, Capeheart, \& Newman, 2006; Jones, 1993; Severance, 2005). Other works find that the nature of America's female prison "pseudo family" may be evolving, and correspondingly, diminishing in importance (Fox 1984; Greer, 2000; Propper, 1982; Severance, 2005). With this in mind, a new way to create supportive networks in prison must be considered (Collica, 2010).

Since women can lack supportive networks and employment skills, prison-based programming may increase opportunities for her institutional and post release success (Bonta \& Andrews, 2007). Programs are a way for women to obtain strong prosocial support during, and possibly after, incarceration (Koons et al, 1997; 
Severance, 2005). However, programs need to be gender-responsive, offender specific, culturally-sensitive and address the differences between men and women in terms of their needs, behaviors and pathways to incarceration in order to be effective (Andrews \& Dowden, 2007; Bloom, Owen, \& Covington, 2004; Bloom \& Covington, 2000). "According to the pathways perspective, the confluence of trauma, substance abuse, and mental health puts women on 'pathways' to crime that are inherently different from the pathways into crime that males take" (Wright et al., 2007, p. 313). When gender-specific policies to address these differences between men and women are absent, women do not receive adequate services to help prepare them for a successful transition.

Identity shifts may be necessary to help women move away from criminal behavior, but such shifts require support (Proctor, 2009). A desire to help others and an aspiration to work in a service profession helps prisoners to transform a deviant identity into a prosocial one (Brown, 1991: Maruna, 2001; Proctor, 2009). It does not ignore the previous identity, but uses the experience from that identity (i.e, working as a counselor with offenders) to successfully adapt to a new prosocial role. For those who are formerly incarcerated, establishing strong bonds to the workplace can begin with the belief that their work allows them to achieve a higher purpose in life. This would include positions that focus on helping others, particularly those who have been through similar life experiences. Prisoners underestimate their abilities and potential (Proctor, 2009), but with support, encouragement, and positive role models, change is possible. In order to change one's trajectory, the prisoner has to come to terms with his or her criminal past and make plans for his or her law abiding future (Maruna, 2001). By helping others, they are able to reform their past, recreate their self identities, and finally accomplish a certain level of success (Lofland, 1969; Nouwen, 1972). The offender does not have to be ashamed of his or her past; he or she utilizes it as a tool to help others. In a study of female desisters in New York City, Sommers, Baskin and Fagin (1994) state, "Overall, the success of identity transformation hinges on the women's abilities to establish and maintain commitments and involvements in conventional aspects of life. As the women began to feel accepted and trusted within some conventional social circles, their determination to exit from crime was strengthened, as were their social and personal identities as noncriminals" (p. 144).

"...The evidence suggests that carefully designed and administered education and work programs can improve prisoners' institutional behavior, reduce recidivism, and promote involvement in prosocial activities after release" (Gaes, Flanagan, Motiuk, \& Stewart, 1999, p. 398). Some programs appear to be more successful than others because they are separate from the rest of the facility (this minimizes distractions), they provide follow-up services (like job placement), and they provide skills that are highly marketable in today's job market (Gerber \& Fritsch, 1995). In a literature review on prison education, Linden \& Perry (1983) find that programs will be most successful if they are "intensive", if they can establish an "alternative community within the prison", and if they offer "post-release services to inmates" (p. 55). Prior research also lends support to the notion that releasees feel more comfortable receiving support from others who are formerly incarcerated (Eaton, 1993). Working in non-traditional prison-based programming, like ACE (AIDS, Counseling \& Education) and CARE (Counseling, AIDS, Resource \& Education), two HIV peer programs, can allow peers the opportunity to form prosocial relationships and attachments with one another, thereby increasing opportunities for reintegrative and rehabilitative success.

\section{Sampling, Methods \& Data}

\section{ACE \& CARE}

This mixed-method study design, based on the narratives of 49 women, examined the effects of two HIV prison-based peer programs on prisoner peers in NYS (New York State): The ACE Program located at Bedford Hills Correctional Facility (BHCF) and the CARE Program located at Taconic Correctional Facility (TCF). ACE educated over 3,000 women annually and CARE educated approximately 600 women annually. The programs consisted of five civilians when fully staffed: a CARE Coordinator, an ACE Coordinator, a HIV Test Counselor, a HIV Discharge Planner, and an Upstate Supervisor. The number of prisoner peers varied (anywhere from 4 to 9). Women in this sample worked for ACE/CARE for an average of 4 years, ranging from 6 months to 13 years. They were trained to provide counseling, educational workshops, and facilitate support groups. In addition, they had permission to work with specialized prison groups such as the nursery mothers, those in the behavioral health unit, those in hospice care, etc. 
Prospective peer workers must have or be working toward their GED. All were required to submit a resume, successfully complete the HIV professional training series (offered by CARE/ACE), undergo two interviews (one by the program coordinator and one by the other prisoner peers), and teach a demonstration lesson. Prospective workers must have a good disciplinary record during the months directly preceding employment. Prisoners with poor records were encouraged to maintain good behavior for a few months before reapplying. Once hired, a poor disciplinary record was grounds for dismissal. Upon securing a peer position, each prisoner staff member was supervised by a civilian (either the ACE or CARE Coordinator) from a community-based organization (Women's Prison Association - WPA). Together, the civilians and prisoners not only delivered comprehensive HIV related services, they created a supportive, community-oriented environment within the prison.

\section{Sample}

The author collected data from female participants over a seven month period, yielding a sample of 49 women. The sample in this study included: (a) women incarcerated in BHCF and TCF who were currently working as peer educators for ACE or CARE at the time of the study, (b) women incarcerated in one of NYS' five female facilities (Albion, Bayview, Beacon, Bedford Hills, or Taconic ${ }^{2}$ ) who previously worked as peer educators for $\mathrm{ACE} / \mathrm{CARE}$ or both programs, and (c) formerly incarcerated women living in the community who, during their incarceration, worked for ACE, CARE, or both programs. Since TCF is a medium-security facility, many women at BHCF who worked for ACE will work for CARE if drafted to TCF. ACE/CARE civilians also worked in both facilities. All participation in this study was voluntary (no incentives were allowed) and all interviews were conducted in private (IRB approval was obtained from the City University of NY and the New York State Department of Corrections and Community Supervision). Forty-nine percent $(n=24)$ of the women were formerly incarcerated and $51 \%(n=25)$ of the women were currently incarcerated at the time of data collection. Based upon extensive one-on-one semi-structured interviews with these women, the author utilized a snowball/chain referral sample to obtain additional participants ${ }^{3}$. Of the 57 women identified and located by the author as matching the study's eligibility requirements (i.e., a current/former peer worker for ACE/CARE), seven women declined to participate, and one woman, incarcerated at Albion, was unable to be interviewed, yielding a response rate of $86 \%(n=49)$. In order to maintain the confidentiality of subjects, women were asked to choose their own pseudonyms, which served as a unique identifier to describe a part of her personality.

Since women could not be randomly assigned to groups (as it would disrupt the prison's regular schedule), between group comparisons were conducted. It was hypothesized that women who worked for the program one year or more or who remained working with the program until their release would have higher levels of attachment to their ACE/CARE peers when compared to those women who worked for ACE/CARE less than one year or left the program prior to their release. It was also hypothesized that women who were responsible for the inception of the program would have greater levels of attachment to their ACE/CARE peers than those women who were not responsible for the creation of ACE/CARE.

Many questions required open-ended responses and yielded in-depth answers. The author examined common themes in answers generated by respondents, utilizing a framework analysis, managing data by case and theme (Glasser \& Strauss, 1967), such as perceptions of peer support and encouragement, concerns regarding peer perception, the maintenance of mutual respect between peers, the utilization of peers to cope with stress, etc. Responses were recorded in written format by the author (tape recording was prohibited) and transcribed later that day. Categorization of responses and themes continued during transcription. It was believed that the use of both quantitative and qualitative measures would increase the validity of participants' responses and provide a fuller understanding of their experiences. To insure the validity and reliability of the

\footnotetext{
${ }^{2}$ Since the completion of this study, Bayview and Beacon Prisons were closed due to a decrease in NYS' inmate population.

${ }^{3}$ The author worked with the creators of ACE/CARE to devise a list of all women who worked for both programs. Out of approximately 65 women identified, 49 were interviewed. Women not included were deported, deceased or unable to be located. Hence, $75 \%$ of all women who worked for both programs participated in this study. Snowball sampling, though not ideal, was the only way to locate subjects. The DOCCS (Department of Corrections and Community Supervision) does not keep records on peer workers.
} 
questions on the interview schedule, questions were borrowed from previous researchers who extensively studied attachment (Alarid et al., 2000; Hirschi, 1969; Friedman \& Rosenbaum, 1988; Lasley, 1998; Rosenbaum, 1987; Sampson \& Laub, 1993; 1990; Shover, Norland, James \& Thornton, 1979; Rankin, 1976). These questions were borrowed from the aforementioned authors and modified to measure attachment levels for current and formerly incarcerated women. For both sets of women, specific questions were asked measuring their levels of attachment to their ACE/CARE coworkers. To measure attachment to their peer coworkers, 14 questions were asked regarding the nature of their relationships, how they viewed their coworkers, and how they thought their coworkers viewed them (see Table One for question item statistics). ${ }^{4}$ To determine if some peers were more likely than other types of peers to have strong attachments to their coworkers, answers to questions on the interview schedule measuring the variable of attachment was assigned a score of one or zero by the interviewer. A score of one signified that there was a high to moderate level of attachment (positive responses), while a score of zero signified that there was a low to no level of attachment (negative responses). Institutional behavior/conduct was measured in terms of disciplinary infractions. Reintegrative success was measured via recidivism data and recidivism was measured in terms of a parole violation and/or an arrest. The adoption of a new "prosocial identity" was measured through self-perception and how participants felt they were perceived by others in their role as a peer educator.

Demographics of the sample differed slightly from the average NYS female prisoner. In this sample, whites tended to be overrepresented (33\% compared to a $22 \%$ rate among the study population), and the age of participants tended to be four years older (40 years old compared to an average of 36 years old among the study population) than the average NYS female prisoner. All women had the equivalent of a high school education or higher. Many of the participants $(33 \% ; n=16)$ were charged with multiple crimes. As to their most serious charge, $49 \%(n=24)$ were serving time for murder or manslaughter, $31 \%(n=15)$ were serving time for a drug-related offense, $12 \%(n=6)$ were serving time for assault, and $2 \%$ were serving time for robbery $(n=1)$, burglary $(n=1)$, kidnapping $(n=1)$, or forgery $(n=1)$. For participants who were incarcerated $(n=25)$, the average time served at the time of the interview was 11 years and six months. For participants who were residing in the community $(n=24)$, the average time served in prison was eight years and eight months.

Prior to incarceration, subjects appeared to have attachments to family and friends, but these bonds were weakened by their behavior. Almost one-half of the women $(43 \% ; n=21)$ were unemployed prior to their incarceration. Over half $(65 \% ; n=32)$ of the sample stated that they earned less than $\$ 10,000$ per year, prior to their arrest, $59 \%(n=29)$ stated that they had children, and most women $(73 \% ; n=36)$ resided with a family member prior to their incarceration. Forty-nine percent $(n=24)$ of the women reported sexual abuse and $45 \%$ $(n=22)$ reported a history of physical abuse. Seventy-one percent $(n=35)$ of the women had a history of drug use/misuse and $41 \%(n=20)$ exchanged sex in order to obtain drugs. Fifty-seven percent $(n=28)$ reported that this was not their first offense. For releasees, 33\% lived alone when they returned home and for incarcerated respondents, less than half (48\%) believed they could reside with a family member/partner upon release: $24 \%$ hoped they could obtain placement in transitional housing, 16\% planned to live alone, and 12\% did not know where they would live. Subjects were involved in other prosocial activity while incarcerated with $86 \%$ of subjects reporting involvement in an educational program, $12 \%$ in a religious program, and 19\% involved with other programs, in addition to their work with ACE/CARE.

It is important to note that most of the women were not HIV positive. Only $14 \%(n=7)$ were diagnosed with HIV; the remaining peers were HIV negative. When asked why they decided to work for ACE/CARE, many of the women maintained that they wanted to help others $(43 \% ; n=21)$, they wanted to educate others and learn more about HIV infection $(39 \% ; n=19)$, they had a loved one who died of AIDS-related complications $(14 \% ; n=7)$, or they wanted to lessen the stigma associated with being HIV positive $(4 \% ; n=2)$.

\section{Findings}

\section{Perceptions of Peer-Related Support}

Social support was vital to the desistance process; the support female prisoners received and the sup-

\footnotetext{
${ }^{4}$ Overall, responses to open-ended questions were given a score of one if they were positive in tone and a score of zero if negative in tone. Likert statements resulting in answers such as all, almost all, many, a lot, most or some received a score of 1, while few, none, not much or not at all received a score of zero.
} 


\section{Table One - Quantitative Measures of Peer Attachment}

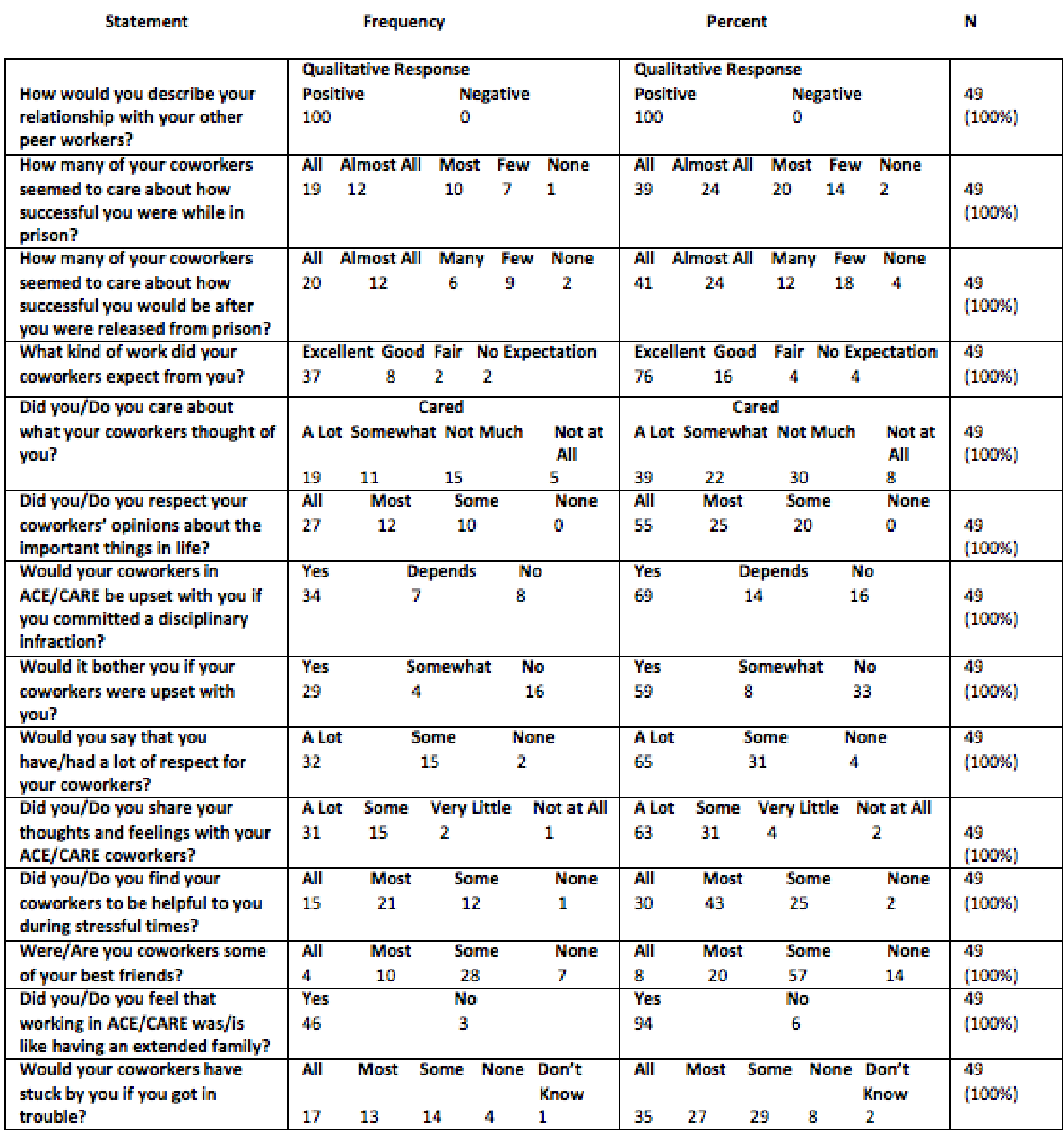

port female prisoners provided were equally as important in this process. In order to measure perceptions of peer-related support, participants were asked a series of questions regarding their feelings toward their coworkers. When participants were asked how they perceived their relationship with their other peer workers, all respondents $(100 \% ; n=49)$ answered positively, regardless of their time with either program. Many participants spoke about their ACE/CARE coworkers as being a source of support, and some referred to their coworkers as family. They recognized they would have arguments and disagreements, but that they were still very close with each other. Shyone (an ACE peer) stated:

Many of us are still great friends today. My closest and dearest friends are the women I had worked with in ACE...

In general, the women who worked for ACE/CARE appeared to share a very strong connection with 
each other. Older members often served as mentors for younger members, recreating a supportive family-like structure. Volcano, an ACE peer, stated:

It was beautiful. We really had a family and some of us were closer than others but we all had each other's back. There was no other place in prison with that type of unity.

Waiting, a CARE peer, 18 years of age, acknowledged the support she received:

It was good. I was the baby. They were my mothers, my big sisters, and my aunts. Everybody had a lot of patience with me.

\section{Promoting Success}

In order to increase one's chances for success, it was necessary for others to emulate and support a similar model of success. To overcome challenges during this process, peers needed to feel that others were invested in their success and cared about what happened to them; it was another important factor in the perception of social support. Ninety-eight percent $(n=48)$ of participants acknowledged that their coworkers seemed to care about how successful they would be while in prison. Although these questions were closed-ended (answers were based on a Likert scale), many of the women spoke openly about each question. Participants spoke about the positive encouragement given to them by their coworkers and described how this enabled them to succeed and excel in the prison environment; responses were not impacted by the length of time in either program:

There was mad love, mad love. We all watched each other grow up. If they saw you doing some thing you weren't supposed to be doing or something that could lead to trouble, they would pull your coat and say, what the hell are you doing? (Rafeequa/ACE Peer)

Ninety-eight percent $(\mathrm{n}=48)$ said their coworkers cared about their success after release:

We all worried about each other. They worried about every one of us when we went home. It was scary to go home because a lot of us were doing a lot of time. (Air/ACE Peer)

High expectations were placed upon the women by one another. Peer workers were asked about the type of work that was expected from them by their coworkers, with $92 \%(n=45)$ who reported "excellent or good":

We were there to do what we were supposed to do. The core group had high standards of work ethics... (Sarabanda/ACE Peer)

\section{Concern Regarding Peer Perceptions}

Attachments can be negatively affected if behavior does not conform to previously established ideas of conduct. A desire to meet these expectations could encourage prosocial behavior. When asked if they cared about what their peers thought about them, 39\% $(n=19)$ stated that they cared "a lot" and 22\% $(n=11)$ said they "somewhat" cared. These women expressed very strong opinions on the subject matter:

I cared a lot about what they thought of my work. You are only as strong as your weakest link and my work reflects on everyone. (Hopeful/ACE \& CARE Peer)

I carried myself in a particular way. As an individual they knew I was outspoken and strong minded within reason. I expected them to know that and I expected them to respect me. They didn't have to agree with me and they didn't have to like me. I didn't have to agree with them and I didn't have to like them but we all had to respect one another. (Marie/ACE peer)

I cared a lot. I may not have portrayed that because I tried to act like it didn't, but it did. I really cared. (Waiting/CARE Peer)

In succeeding questions, the majority of the women stated they respected their coworkers' opinions 
and they would be bothered if their coworkers were upset with them. When asked if they respected their coworkers' opinions about the important things in life, 55\% $(n=27)$ said all, 25\% $(n=12)$ said most, and $20 \%$ $(\mathrm{n}=10)$ said some. Even if the women did not agree with what was being said, they respected a peer's right to express her opinion:

You reserve the right to be who you are. Even if I don't like what you are saying, I respect your right to say it and I won't interfere. (Face/ACE Peer)

Since the women were very aware that their behaviors reflected upon the program, questions were asked to determine if they thought the peers would be upset with them if they committed a disciplinary infraction. Sixty-nine percent $(n=34)$ said their peers would be upset with them, $14 \%(n=7)$ said it would depend upon the reason for the ticket, and $16 \%(n=8)$ said they would not be troubled if their peers were upset with them. Many of the women believed that prisoners would often receive tickets in prison, even if the disciplinary infraction was not justified. Their peers would be upset with them if it was a situation that could have been avoided. Whether they were right or wrong, the women believed that even if their peers were upset with their behavior, they would not relinquish their support:

We all had our share. It is easy to get a disciplinary infraction in here. You can get one for breathing wrong. You can get one because you are the victim of an officer having a bad day. (Compassionate/ ACE Peer)

We would talk each other out of doing crazy things but it would depend on what it was for. If it was something stupid that I did, than yes, they would be upset with me but if I couldn't avoid it, than no. (Rose/ACE Peer)

When asked if it would bother them if their coworkers were upset with them, $59 \%(n=29)$ said yes, $8 \%(n=4)$ said somewhat, and $33 \%(n=16)$ said no. Those women who stated "yes" perceived the peers to be a family unit, whose members would not want to be upset or disappointed. The essence of the "prosocial identity" was noted in the women's perceptions of self. The view of being a role model, characteristic of a prosocial identity, was echoed several times and appeared to have a strong impact on decision making:

We were looked at as role models to others, to everybody. (Mary/ACE)

... We were seen as someone to look up to, a role model. (Sky/CARE)

For those women who stated that they would not be bothered, there was a feeling that they were responsible for their own decisions and they hoped that the peers would be understanding:

I don't know if they would be upset as much as disappointed. I would not really be upset because I would get what the hand called for. There were unwritten expectations placed on us. The women who didn't work for CARE looked up to us and the correctional staff placed expectations on us - we had privileges. (Shak/CARE Peer)

Yes. It would have bothered me more if they weren't upset with me. I would have been disappointed. (Purposed/ACE Peer)

\section{Mutual Respect}

The variable of attachment to peers was also measured by asking participants if they had a lot of respect for their ACE/CARE peers and if they shared their thoughts and feelings with them often. Sixty-five percent $(n=32)$ of respondents stated that they had a lot of respect for their peers, $31 \%(n=15)$ stated they only had respect for some of their peers, while $4 \%(n=2)$ said they did not have any respect for their peers. Most of the women stated that even if they did not like a particular peer, they still possessed the ability to respect her and the work that she was trying to accomplish within the program:

I respected them a lot even if I didn't like them because they could reach someone that I possibly 
couldn't. They were all assets to the program. (Scarlet/ACE)

I respected some of the women I worked with as people and for those that I didn't respect as people, I did respect the work that they did. (Face/ACE)

\section{Coping With Stress through Peer-Relational Support Networks}

Incarceration was extremely stressful, particularly for female prisoners, many of whom suffered emotionally because of the separation from their family and children. If stress was left unmanaged, it could have resulted in maladaptive behavior (Celinska \& Sung, 2014). In order to gain a greater understanding of the types of stresses these women experienced during their incarceration, they were asked to describe the most stressful part about being in prison. Fifty-three percent $(n=26)$ of the sample stated that the separation from family was the most difficult, particularly being separated from their children and the constant worry about their children's well being. Many of these participants also had to deal with the loss of a family member while in prison. Other participants reported that they felt powerless or they hated being locked-in, having no freedom and little privacy. Others expressed concern over the inconsistencies in the rules, being dehumanized, having to take orders, and going in front of the parole board:

The inconsistency within the prison. Five minutes ago you could do something and five minutes later you can’t. (Yasmeen, ACE Peer)

\section{Losing my mother while I was in there. (Marie/ACE \& CARE Peer)}

Not being able to do what I want to do and need to do. You are stagnated in here. You have no life. You're just existing. (Free/CARE Peer)

Coping with this stress and being able to talk about it with others distinguished one's prison sentence from being hard time or harder time. Having the ability to speak freely with other women in the program provided an appropriate outlet for stress and allowed them to manage their stress more effectively. Sharing one's feelings was one way to alleviate some of the associated stress. In terms of sharing their thoughts and feelings with their coworkers, $63 \%(n=31)$ said they shared a lot, 31\% $(n=15)$ said they shared some of the time, $4 \%$ $(\mathrm{n}=2)$ said that they shared very little, and $2 \%(\mathrm{n}=1)$ did not share anything at all. When asked how many of their coworkers were helpful during stressful times, 30\% $(n=15)$ said all of them were helpful, $43 \%(n=21)$ said most, $25 \%(\mathrm{n}=12)$ said some, and only $2 \%(\mathrm{n}=1)$ said none:

They were my biggest support system when my daughter died. ... The ACE women were really there for me because it was my most difficult time. (Volcano/ACE)

Many of the women had at least one peer in ACE/CARE who they considered to be a best friend. When asked if they considered their coworkers to be some of their best friends, $8 \%(n=4)$ said all, 20\% $(n=10)$ said most, $57 \%(\mathrm{n}=28)$ said some, and $14 \%(\mathrm{n}=7)$ said none:

We were close friends and we were always there for each other. We spent a lot of time outside of work together. If one of us was having a stressful day, we would meet in the yard to talk about it. If one of us lost a patient, we had a sit down to talk about it. (Hopeful/ACE \& CARE)

When asked if they felt like working for ACE/CARE was like having an extended family, an overwhelming majority of women $(94 \%)(n=46)$ answered affirmatively; this was not affected by time spent in either program. This feeling of family was very important and something that appeared to help them through difficult periods. When asked how many of their coworkers would have stuck by them if they had gotten into any type of trouble, 35\% ( $n=17)$ said all of them, $27 \%(n=13)$ said most of them, $29 \%(n=14)$ said some of them, $8 \%(n=4)$ said none of them, and $2 \%(n=1)$ said they did not know. Having peer/staff support was something the women expected; however, this support was conditional. There was the feeling that if they engaged in behavior that would jeopardize the program, they would not be entitled to staff support:

There was one crazy situation but they stuck by me. Only a few hesitated. People would stick by me 
in however capable they were able to do so. (Annie/ACE Peer)

There was a very special bond between us. If anyone went to lock or was removed from the program, we gave them support. It was like a family. (W21/ACE Peer)

We would keep each other on the up and up. If someone was straying, we would say what's up, what's going on? If we had to, we would kick them out of the program. Everything about you reflected upon the program. You could not just leave the room and said that you weren't in ACE so you could do whatever you wanted. ACE followed us everywhere at every time and we had to be mindful of our behavior. (Sarabanda/ACE Peer)

\section{Desire to Maintain Peer Relationships Upon Release}

Bonds of attachment were important for successful reintegration (Valera et al., 2015). If family bonds were weak or non-existent, relationships maintained with one another could help to mitigate feelings of isolation while encouraging support for new prosocial identities. Incarcerated respondents strongly desired maintaining contact with their ACE/CARE coworkers $(84 \%)(n=41)$ upon being released. When asked if they planned to keep in contact with their ACE/CARE coworkers, $4 \%(n=2)$ said they would keep in contact with all of them, $12 \%(n=6)$ said most of them, $68 \%(n=33)$ said some of them, $12 \%(n=6)$ said none of them, and $4 \%(n=2)$ said they did not know if they would maintain contact. Two respondents expressed concern that although they would like to maintain contact with their coworkers after release, they did not want to violate one of the conditions of their parole by associating with "another known felon."

Twenty-two out of 24 releasees (92\%) kept in contact with their former ACE/CARE peer workers since their release. Only two peers did not maintain contact with any of their former coworkers; they said it was not intentional, and they just lost track of everyone. One of these women gave me her business card and asked me to distribute it to other former ACE members who I might be interviewing. She was anxious to reconnect with many of her peers. For the other 22 women, 18 stated they maintained contact with most of their peers and four women said they maintained contact with some of their peers. None of the women managed to stay in contact with all of their peers: $17 \%(n=8)$ maintained contact with one coworker, $29 \%(n=14)$ with two coworkers, $13 \%(n=6)$ with three coworkers, $13 \%(n=6)$ with four coworkers, $4 \%(n=2)$ with five coworkers, $4 \%(n=2)$ with six coworkers, and three women $(13 \%)$ maintained contact with ten former coworkers. On average, the women spoke to their former coworkers approximately ten times per year, ranging from two women who spoke to their former coworkers weekly and five women who spoke to their coworkers only twice per year. Seventy-nine percent of releasees stated that their coworkers were still a continued source of support for them, which appeared to reinforce institutional/post release success and preservation of a prosocial lifestyle.

\section{Overall Attachment Levels}

In measuring levels of attachment quantitatively, the highest score a respondent could obtain was 14 points, while the lowest score was a zero. Overall, the score for attachment to coworkers for both groups (i.e., those who stayed with the program until their release verses those who left the program prior to their release and those who created the program verses those who did not create the program) was fairly high (mean=10.6; median $=11$; mode $=11$ ) (see Figure 1 ). ${ }^{5}$ Those who stayed with the program until their release had slightly higher levels of attachment to their coworkers than those who did not stay with the program until their release (average scores of 11 verses 10 respectively) (see Figure 2). When comparing those who created the program to those who were not responsible for creating the program, levels of attachment were higher for the first group

\footnotetext{
${ }^{5}$ These differences, when utilizing the Mann-Whitney test, a nonparametric test to compare the means of two independent samples, where the population is not assumed to be normally distributed, did not prove to be statistically significant (Mann-Whitney $U$ statistic $=202$; Wilcoxon $W$ statistic $=608$ ). The associated $p$ value of .059 was not statistically significant at the $<0.0005$ level. This test requires 4 assumptions: the dependent variable must be ordinal (attachment score), the independent variable must have two categorical groups (creators $v$ non-creators or stayed with the program $v$ left the program), there must be an independence of observations (participants can only be in one group), and the two groups are not normally distributed.
} 
of peers (average attachment score of 12 verses 10) when compared to the latter group (see Figure 3 ). ${ }^{6}$ None of the differences between groups were statistically significant.

\section{Overall Coworker Attachment}

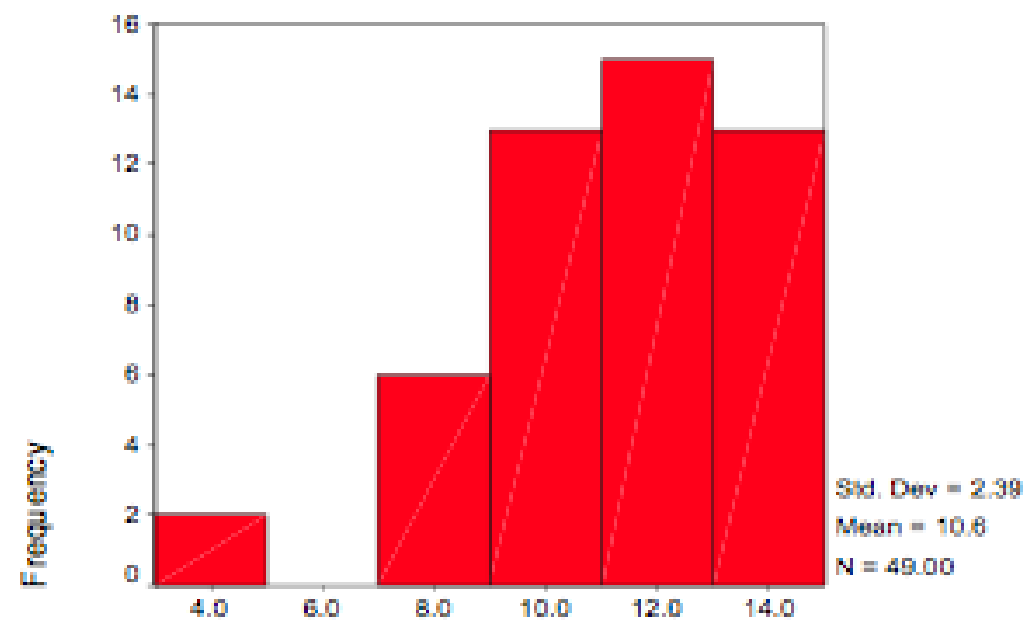

Attachment Score

Figure 1.

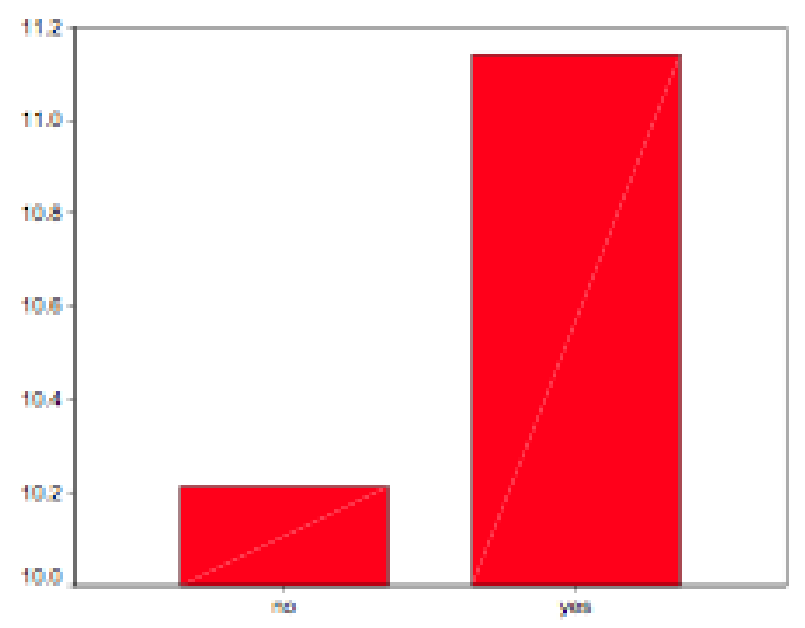

Stayed Unal Release

Figure 2. Attachment--stayed until release vs. leaving prior to release.

\section{Discipline \& Institutional Conduct, \& Recidivism}

Levels of attachment could directly affect institutional and postrelease conduct. To determine if working in ACE/CARE had an effect on the rate of tickets incurred, respondents were asked to report on the total number of tickets they received prior to and during the time they were employed with ACE/CARE. The author was unable to obtain permission to view the participants' official institutional disciplinary record and thus relied solely upon self-report data. In looking at the effect that ACE/CARE had on rates of disciplinary infractions among participants, more than one-half of participants $(51 \% ; n=25)$ had a decrease in the number of tickets they received after joining ACE/CARE. On average, the women had received 5.17 tickets prior to

${ }^{6}$ These differences, when utilizing the Mann-Whitney Test, did not prove to be statistically significant (Mann-Whitney U statistic=182.5; Wilcoxon W statistic=777.5). The associated $\mathrm{p}$ value of .110 was not statistically significant at the $<0.0005$ level. 
working for ACE/CARE (.59 tier ones, 4.10 tier twos, .52 tier three) (tier ones are the least serious and tier

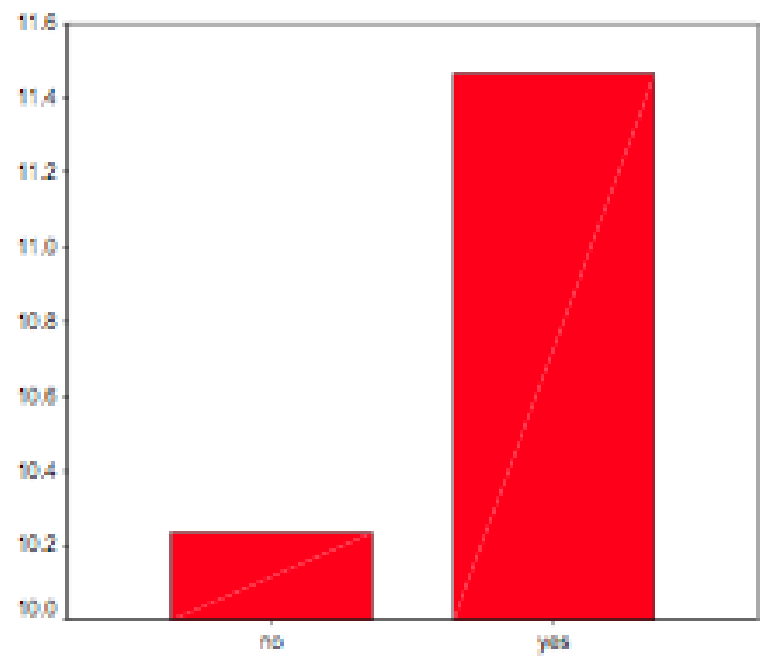

Crested ACECARE

Figure 3. Attachment--program creators vs. non-creators.

threes are the most serious), and they only received, on average, 1 ticket (.95) during the time they worked for ACE/CARE (.19 tier ones, .70 tier twos, .10 tier threes). ${ }^{7}$

In examining the rate of postrelease success, most releasees were employed at the time of the interview ( 21 out of 25 women). On average, releasees were living in the community for five years (median=4 years; mode $=10$ years) since their release from prison, ranging from the shortest time out of prison at one year and the longest time out of prison at 15 years. Seventy-two percent $(n=18)$ of the women worked for community-based organizations providing social services such as HIV-related services, mental health services, or substance abuse services. Studies showed that after five years of release, the possibility of recidivating was extremely improbable (Human Rights Watch, 2004). Only one of the releasees was arrested since leaving prison. Nonetheless, her transgression was quite minor and she was not violated.

\section{The Importance of Prisoner Bonds}

Interview data indicated that some women had bonds prior to prison but were able to develop another set of supportive bonds through ACE/CARE, while others had very little in terms of relationships prior to prison and relied primarily upon the bonds cultivated from ACE/CARE. In either case, ACE/CARE impacted women who had many bonds, few bonds or no bonds prior to working for ACE/CARE; all prisoners benefited from their work in these two programs. For HIV peers, work within ACE/CARE was one factor that led or could lead to their success, but confounding factors and additional support systems, even within the prison, were also important in some cases:

My support system [ACE, friends and family] and having the fundamentals I learned from ACE and the family violence program [were contributing factors to my success]. I learned coping skills. I learned that you don't start making plans about your future when you come out; it starts the first day you step inside. That's what ACE gave me. It helped me to start the transition before I even left (Sarabanda/ACE).

\footnotetext{
${ }^{7}$ In conducting a pair samples T test, the associated p value of .537 (comparing tickets incurred before and during work with ACE/ CARE) and the associated $p$ value of .839 (comparing tickets incurred during and after work with ACE/CARE) were not statistically significant at the $<0.0005$ level.
} 
Most women reported that they had family $(n=41 ; 84 \%)$ and friends $(n=41 ; 84 \%)$ who acted as a source of support for them prior to their arrest. This was not the first arrest for over half of this sample ( $\mathrm{n}=28$; $57 \%)$, and the majority $(\mathrm{n}=35 ; 71 \%)$ were using or misusing drugs and/or alcohol prior to their arrest. Approximately half $(\mathrm{n}=26 ; 53 \%)$ had the equivalent of a high school diploma prior to admission, and although more than half were employed $(n=28 ; 57 \%), 43 \%(n=21)$ were unemployed and had no income at all. Out of those employed, the majority was employed in low level positions with $30 \%(\mathrm{n}=15)$ making $\$ 20,000$ or less before their incarceration. If you included those with no legal income, $73 \%(n=36)$ made between $\$ 0$ and $\$ 20,000$ the year prior to their arrest.

Not all respondents lacked prosocial bonds prior to prison, but their work in ACE/CARE appeared to facilitate additional bonds for all respondents. Peer bonds worked in two distinct ways. First, for all respondents, a commitment to achieving a prosocial identity began before their employment with ACE/CARE. As discussed earlier, prisoners with poor disciplinary records and prisoners with less than a high school education were encouraged to remediate these issues and reapply. This served as a motivator for those who were interested in making a change, but that interest did not yet equate to a concrete change in their behavior. For these women, ACE/CARE created new opportunities to strengthen their desire to have a prosocial identity. During the interviews, several women (Blondie, Ten, No Excuses, Waiting, Ace and Rafeequa) specifically stated that without the opportunity to work for ACE/CARE, their disciplinary issues would have continued or worsened. Released women spoke about the impact working for ACE/CARE had on their postrelease success and its ability to facilitate the opportunity for successful reentry, while incarcerated women spoke about the impact working for ACE/CARE would have on their postrelease success and its ability to facilitate the opportunity for successful reentry. Ninety percent of the sample stated that working in ACE/CARE helped them or would help them successfully transition from prison to the community. Twenty three incarcerated women $(n=88 \%)$ felt that ACE/CARE would prove to facilitate a successful transition:

It taught me how to be a counselor. Most likely when I get home, this will be the first job I get. (Ten/ACE)

I want to continue my work with patient care. The ACE program gave me wisdom and increased knowledge that I will use on the outside (Compassionate/ACE).

Twenty-two released women (96\%) attributed their post-release success to ACE/CARE. It was a common theme throughout almost all of their narratives and showed that these prosocial identities remained with them after release:

All the people I was around assisted me in the transition from prison to the community. There was a support system in place for me (Smarty/ACE).

I am now employed in the HIV field. My whole resume says HIV. I am now a facilitator working on being a case manager (Blondie/CARE).

It helped me to put job skills on my resume. I am grateful for the skills I developed which is what helped me to get a good job. It is always interesting to say that you were part of this program (Pow er/ACE \& CARE).

It gave me the outside support I needed and I was able to access resources that I otherwise wouldn't have had. I also had experience and that experience made me marketable (Nicolette/ACE \& CARE)

Second, for released women who did not have disciplinary problems prior to being with the program or who may have been working in other prison programs prior to ACE/CARE, ACE/CARE allowed them to continue to build additional prosocial bonds in a way they felt was meaningful. Regardless of other influences, they believed that ACE/CARE was an important factor in their success:

I was originally in GBS (General Business School) but I wanted to help people and didn't know how. I was able to do that through ACE. It gave me the skills I needed to use when I got home (Big Sis - 


\section{$\mathrm{ACE} / \mathrm{CARE})$}

If it were not for ACE and family violence, I would not be where I am at today. I would not be as successful as I am. I was involved with the family violence program, I had 1:1 with counselors, I was involved in support groups and I shared in ACE. I had a family in ACE and even today I miss those family dynamics. It's different in prison because you choose the people in your family. People think you don't have a choice but you do and you choose to be around them because you really care about the family you created. On the outside, you don't have a choice about who is in your family. In prison it was a choice and ACE was my family (Sarabanda/ACE)

\section{Discussion}

ACE/CARE members had very high levels of attachment to their ACE/CARE coworkers. By cultivating opportunities to create a network of supportive bonds, working in an HIV prison-based peer program may be the first stop of many on the "desistance line," eventually leading to the final destination of adopting a newfound prosocial identity. These peers $(94 \% ; n=46)$ maintained that being in ACE/CARE was like being part of a family. Older members acted as mentors for younger members and the majority of the women found peer staff to be a strong source of support for them. While incarcerated, the peers expressed that separation from family was the most stressful aspect of incarceration and being a part of ACE/CARE assisted in ameliorating these stress inducing factors. The women were able to speak openly in ACE/CARE, with 94\% ( $n=46)$ of peers who reported sharing their thoughts and feelings with their coworkers. The peers had great respect for one another and they encouraged the adoption of new prosocial roles. The notion of being a role model, characteristic of a prosocial identity, was echoed several times and appeared to have a strong impact on decision making.

Peers expressed concern about each other's success inside of the institution, in addition to expressing concern about each other's success after release from prison. They strongly cared about one another's opinions regarding their actions and behavior. Even after release, these women still desired to maintain a connection with their ACE/CARE peers and in essence, they wanted their peers to be proud of them. Peers had low rates of disciplinary infractions and releasees had extremely low recidivism, demonstrating reintegrative success. Overall, respondents had very high levels of attachment to coworkers (average score of 10.6 out of 14 points). Upon conducting between group comparisons, small differences were found between the groups, but none of the differences proved to be statistically significant. Even after release, these women still desired to maintain a connection with their ACE/CARE peers and relied upon their peers for support during this difficult transition. All prisoners benefited from their work in these two programs: some women had bonds prior to prison but were able to develop another set of supportive bonds through ACE/CARE, while others had very little in terms of relationships prior to prison and relied primarily upon the bonds created with their coworkers in ACE/CARE.

This program allowed female prisoners to obtain marketable job skills, enabling them to transcend traditional prison-based programs which often prepared women to work in "pink collar," underpaid employment. The subservient role of women in society was reflected within the prison environment, as prison is often a larger reflection of societal problems like racism, classism, and sexism. Since women were not afforded as many vocational and educational opportunities as men while in prison, these acquiescent roles were perpetuated by the correctional system in its failure to provide skills-equality (Moyer, 1984; Smart, 1976). Due to their smaller numbers, correctional officials were often able to rationalize circumventing the programmatic needs of female prisoners (Bonta, Pang, \& Wallace-Capretta, 1995). Even today, most of the jobs that women were assigned to in the prison system focused on domestic work and did not teach the women relevant job skills, but only helped in the daily maintenance of the institution (Dobash, Dobash \& Gutteridge, 1986; Pollack-Byrne, 1990). This provided no opportunity for rehabilitation or for the attainment of valuable job skills, which would have afforded them the opportunity to be able to support themselves and their family upon release (Pollack-Byrne, 1990). Seventy-two percent of releasees in this study were working in public health related fields. ACE/CARE gave women the skills to work in entry-level positions in the field of public health, where the stigma of incarceration was an asset rather than a liability. These women were experts at working 
with at-risk populations. The appropriate job skills, coupled with support, provided an incentive to maintain law-abiding behavior.

\section{Limitations}

There were several limitations to the current study. First, the sample was not random since it was an already established program within the prison. Second, there was an issue of selection-bias, particularly when using snowball sampling. Nonetheless, $75 \%$ of all women who worked for both programs participated in this study. Snowball sampling, though not ideal, was the only way to locate participants. Third, there was no control group in this study. The facility was not able to provide the author with record data to serve as another method of comparison. It was also not feasible (or allowable) to have another group of inmates taken from their regularly scheduled programs to participate in a comparison group, as this would have disrupted the daily schedule of the prison facility. Rather, comparisons were made between groups. Between-group comparisons (those responsible for creating the program $\mathrm{v}$ those responsible for not creating program and those who stayed in the program for one year $\mathrm{v}$ those who did not stay for one year) did not produce statistically significant differences. In fact, no notable differences were observed, demonstrating that regardless of time spent within the program, and irrespective of one being involved in the development of the program, these programs served a beneficial purpose for female prisoners.

\section{Implications \& Future Research}

The effects of non-traditional prison-based programming on prisoner attachments are encouraging. Programs like ACE/CARE benefit facilities by providing comprehensive education/counseling services free to the inmate population and by increasing overall knowledge about HIV and risky behaviors (Collica, 2002; Hammett, Harmon, \& Maruschak, 1999; Keeton \& Swanson, 1988). They assist in increasing self-esteem (Collica-Cox, 2015; Hammet, et al., 1999), they build supportive communities and networks (Collica, 2010; Eaton, 1993), they reduce disciplinary infractions (Collica-Cox, 2014) and they reduce recidivism by promoting viable employment opportunities for females offenders (Collica, 2013; Hammet et al., 1999). Unemployment prior to arrest, coupled with a conviction record, can seriously hinder job prospects for newly released prisoners (Richie, 2001; Uggen, 2000). By providing prisoners with strong bonds (Benda, 2005; Li \& Mackenzie, 2003), employment can decrease crime at a higher rate, particularly among older prisoners (Uggen, 2000) and prolong the time between release and reoffending (Tripodi, 2010), reducing the overall chances for recidivism. Affording prisoners with the skills to obtain a career can provide the motivation necessary to maintain the desistance process (Maruna, 2001). Prosocial peers are correlated with decreased criminal activity and can serve as a mechanism to replace earlier deviant associations (Wright \& Cullen, 2004). The less one associates with deviant peers, and the more one is supported by prosocial peers, the more likely one will have the support to sustain law abiding behavior.

Unfortunately, many prisons underutilize these programs (Collica, 2007; Hammet, et al., 1999). An unintended additional benefit of such programs is their ability to cultivate strong prosocial attachments with their incarcerated coworkers. These peer workers serve as a source of support for newfound prosocial identities, a vital component to rehabilitative and reintegrative success. Incarceration can increase stigma, which reduces the strength of social bonds, yet, supportive prosocial attachments can protect prisoners' feelings from the negative effects of labeling (Berger, Estwing Ferrons, \& Lashley, 2001; LeBel, 2012).

Female facilities suffer from a paucity of prison programming (Belknap, 2015), and since their needs tend to be more diverse and more substantial than the needs of their male counterparts, increasing and expanding such programming is essential. If female prisoners continue to be trained in "pink collar" employment (i.e., food service, secretarial, etc), they will be unable to support themselves or their children upon release. Skills learned in traditional women's prison-based vocational programs are not marketable (Belknap, 2015). Women face many difficulties when returning home (i.e., recovery, mental health issues, medical problems, child care, post-traumatic stress disorder from abusive and violent relationships, difficulty in securing affordable housing, inadequate education, lack of employment skills or history, etc.) (Richie, 2001), but female prisoners trained in HIV peer education can and will be able to obtain substantial employment opportunities in major metropolitan cities upon release. These programs empower women to be financially independent and can serve as a stepping stone to lifetime careers in the field of public health. Women involved in these 
programs are invested in working in the field of HIV, even though most are not HIV positive. These programs provide women with a new identity, which allows them to reform and reclaim their lives (Maruna, 2001).

More research should be conducted on the effects of non-traditional programming on female prisoners, particularly focusing on the ability of attachments to predict or explain female patterns of criminality. Peer programming does not have to be HIV focused; in fact, any program, when managed well, may have the ability to produce similar effects. Further study on non-traditional programs can shed light on the fact that often the program itself is not as important as the way in which the program is managed. Program management impacts a program's success and its ability to promote prosocial behavior, enhancing one's investment in social capital.

Acknowledgements: A special thank you and appreciation to all of the ACE \& CARE women; your work is important and noticed. Thanks to the New York State Department of Correctional Services and Community Supervision for allowing this project.

\section{References}

ACE (AIDS Counseling and Education Program). (1998). Breaking the walls of silence: AIDS and women in a New York State maximum-security prison. Woodstock and New York:

Overlook Press. doi: http://dx.doi.org/10.1016/S1055-3290(06)60324-5

Amnesty International. (2016). Mass incarceration in the USA. Retrieved from:

http://www.amnestyusa.org/our-work/issues/military-police-and-arms/police-and-humanrights/mass-incarceration-in-the-usa

Alarid, L. F., Burton, V. S., \& Cullen, F. T. (2000). Gender and Crime Among Felony Offenders: Assessing the Generality of Social Control and Differential Association Theories. Journal of Research in Crime and Delinquency 37 (2), 171-199.

doi: $10.1177 / 0022427800037002002$

Andrews, D. \& Dowden, C. (2007). The Risk-Need-Responsivity Model of Assessment and Human Service in Prevention and Corrections: Crime-Prevention Jurisprudence. Canadian Journal of Criminology and Criminal Justice, 49 (4), 439-464.

doi: http://dx.doi.org/10.3138/cjccj.49.4.439

Bahr, S. J., Armstrong, A. H., Gibbs, B. G., Harris, P. E., \& Fisher, J. K. (2005). The reentry process: How paroles adjust to release from prison. Fathering: A Journal of Theory,

Research, and Practice About Men as Fathers, 3 (3), 243-265.

Bales, W. D., \& Mears, D. P. (2008). Inmate social ties and the transition to society: Does visitation reduce recidivism? Journal of Research in Crime and Delinquency, 45, 287-321. doi: $10.1177 / 0022427808317574$

Belknap, J. (2015). The invisible woman. CT: Cengage.

Belknap, J. (1996). Access to programs and health care for incarcerated women. Federal Probation. Corrections Today, 60 (4), 106-111.

Benda, B. (2005). Gender differences in life-course theory of recidivism: A survival analysis. International Journal of Offender Therapy and Comparative Criminology, 49, 325-342. doi: 10.1177/0306624X04271194

Berger, B. E., Estwing Ferrons, C., \& Lashley, F. R. (2001). Measuring stigma in people with 
HIV: Psychometric assessment of the HIV stigma scale. Research in Nursing and Health, 24, 518-529. doi: 10.1002/nur.10011

Bersani, B., Laub, J., \& Nieuwbeerta, P. (2009). Marriage and desistance from crime in the Netherlands: Do gender and socio-historical context matter? Journal of Quantitative Criminology, 25, 3-24. doi: 10.1007/s10940-008-9056-4

Bloom, B., \& Covington, S. (2000, November). Gendered justice: Programming for women in correctional settings. Paper presented to the American Society of Criminology, San Francisco, CA. Retrieved from: http://www.centerforgenderandjustice.org/assets/files/11.pdf

Bloom, B., Own, B., \& Covington, S. (2004). Women offenders and the gendered effects of public policy. Review of Policy Research, 21 (1), 31-48. doi: 10.1111/j.15411338.2004.00056.x

Bonta, J., \& Andrews, D. A. (2007). Risk-Need-Responsivity Model for Offender Assessment and Rehabilitation. Public Safety Canada. Retrieved from: https://cpoc.memberclicks.net/assets/Realignment/risk_need_2007-06_e.pdf

Bonta, J., Pang, B., \& Wallace-Capretta, S. (1995). Predicators of recidivism among incarcerated female offenders. The Prison Journal, 75 (3), 277-294.

doi: $10.1177 / 0032855595075003002$

Booth, J. A., Farrell, A., \& Varano, S . P. (2008). Social control. Serious delinquency, \& risky behavior. A gendered analysis. Crime \& Delinquency, 54 (3), 423-456.

doi:10.1177/0011128707306121

Boudin, K. (1993). Participatory Literacy Education behind Bars: AIDS Opens the Door. Harvard Education Review, 63 (2), 207-232. doi: http://dx.doi.org/10.17763/haer.63.2.t875w42q30w8qk04

Brown, J. D. (1991). The professional ex-: An alternative for exiting the deviant career," The Sociological Quarterly 32, (2), 219-230. doi: 10.1111/j.1533-8525.1991.tb00354.x Burton, V. (1991). Explaining adult criminality: Testing Strain, differential association, and control theories. Unpublished dissertation: University of Cincinnati.

CDC. (2016). HIV infection among incarcerated populations. Retrieved from: http:/www.cdc.gov/hiv/group/correctional.html

Celinska, K., \& Sung, H. (2014). Gender differences in the determinants of prison rule violations. The Prison Journal, 94 (2), 220-241. doi:10.1177/0032885514524882

Chapple, C. L., Hope, T. L., \& Whiteford, S. W. (2005). The direct and indirect effects of parental bonds, parental drug use, \& self control on adolescent substance use. Journal of child and adolescence Substance Abuse, 14 (3), 17-38. http://dx.doi.org/10.1300/J029v14n03_02

Chriss, J. J. (2007). The functions of the social bond. Sociological Quarterly, 48 (4), 689-712. doi: 10.1111/j.1533-8525.2007.00097.x

Clemmer, D. (1940). The prison community. New York: Holt, Rinehart \& Winston.

Cloyes, K. G., Rosenkranz, S. J., Berry, P. H, Supiano, K. P., Routt, M. ,Shannon-Dorcy, K. , \& Llanque, S. M. (2016). Essential elements of an effective prison hospice program. American Journal of Hospice \& Palliative Medicine, 33 (4), 390-402. doi:10.1177/1049909115574491 
Cloyes, K. G., Rosenkranz, S. J., Wold, D., Berry, P. H., \& Supiano, K. P. (2014). To be truly alive: Motivation among prison inmate hospice volunteers and the transformative process of end-of-life peer care service. American Journal of Hospice \& Palliative Medicine, 31 (7), 735-748. doi: 10.1177/1049909113506035

Cobbina, J. E., Huebner, B. M. \& Berg, M. T. (2012). Men, women, and postrelease offending: An examination of the nature of the link between relational ties and recidivism. Crime \& Delinquency 58 (3), 331-361. doi:10.1177/0011128710382348

Collica-Cox, K. (2015). Feeling Positive about HIV: Prison-Based Peer Educators and Self- Esteem. Journal of Correctional Education, 66 (1), 21-44.

Collica-Cox, K. (2014). Counting Down: HIV Prison-Based Peer Education Programs and Their Connection to Reduced Disciplinary Infractions. International Journal of Offender Therapy and Comparative Criminology, 58 (8), 931-952. doi: 10.1177/0306624X13490660.

Collica, K. (2013). Female Prisoners, AIDS, and Peer Programs: How Female Offenders Transform Their Lives. New York \& London: Springer Publishing. doi: 10.1007/978-14614-5110-5

Collica, K. (2010). Surviving Incarceration: HIV Prison-Based Peer Programs Build Communities of Support for Female Offenders. Deviant Behavior, 31 (4), 303-313. http://dx.doi.org/10.1080/01639620903004812

Collica, K. (2007). The Prevalence of HIV Peer Programming in American Prisons: An opportunity wasted. Journal of Correctional Healthcare, 13 (4), 278-288. doi: $10.1177 / 1078345807306865$

Collica, K. (2002). Levels of Knowledge and Risk Perceptions about HIV/AIDS Among Female Inmates in New York State: Can Prison-Based HIV Programs Set The Stage for Behavior Change? The Prison Journal, 82 (1), 101-123. doi: $10.1177 / 003288550208200107$

Colvin, M., Cullen, F. T., \& Vander Ven, T. (2002). Coercion, social support, and crime: An emerging theoretical consensus. Criminology, 40, 19-42. doi: 10.1111/j.17459125.2002.tb00948.x

Cretacco, M. A., Fei Ding, M. L., \& Rivera, C. J. (2010). Traditional and bond measures of self-control and their impact on deviance among Chinese university students. International Journal of Criminal Justice Sciences, 5 (1), 220-238. Retrieved from: http://www.sascv.org/ijcjs/pdfs/michaeletaljcjs2010vol5iss1.pdf

Cullen, F. T. (1994). Social support as an organizing concept for criminology: Presidential address to the Academy of Criminal Justice Sciences. Justice Quarterly 11, 527-560. http://dx.doi.org/10.1080/07418829400092421

DeBell, J. (2001). The Female Offender. Corrections Today, 63, (1), 56-62.

Deschenes, E. P., Owen, B., \& Crow, J. (2006). Recidivism among female prisoners:

Secondary analysis of the 1994 BJS recidivism data set. Department of Justice. Retrieved from: https://www.ncjrs.gov/pdffiles1/nij/grants/216950.pdf

Dobash, R., Dobash, R. E., \& Gutteridge, S. (1986). The imprisonment of women. Basil 
Blackwell: New York.

Dodge, M., \& Pogrebin, M. P. (2014). Collateral costs of imprisonment for women:

Complications of reintegration. The Prison Journal, 81 (1), 42-54.

doi: $10.1177 / 0032885501081001004$

Dow, H. D. (2001). Attachment issues, trauma \& psychopathology among incarcerated women. American Jails, 25 (4), 27-36.

Durose, M. R., Cooper, A. D., \& Sydner, H. N. (2014). Recidivism of prisoners released in 30 states in 2005: Patterns from 2005 to 2010. Washington DC: US Department of Justice.

Retrieved from: http://www.bjs.gov/content/pub/pdf/rprts05p0510.pdf

Eaton, M. (1993). Women after Prison. Pennsylvania: Open University Press.

Fox, J. (1984). Women's prison policy, prisoner activism, and the impact of the Contemporary feminist movement: A case study. The Prison Journal, 64 (2), 15-36. doi: $10.1177 / 003288558406400103$

Friedman, J., \& Rosenbaum, D. (1988). Social control theory: The salience of components by age, gender, and type of crime. Journal of Quantitative Criminology, 4 (4), 363-381. doi:10.1007/BF01065345

Gaes, G., Flanagan, T., Motiuk, L. \& Stewart, L. (1999). Adult correction treatment. Prisons (ed by Tonry, M. \& Petersilis, J). Chicago: University of Chicago Press.

Gerber, J. \& Fritsch, E. (1995). Adult academic and vocational correctional education Programs: A review of recent research. Journal of Offender Rehabilitation, 22 (1/2), 119-142. http://dx.doi.org/10.1300/J076v22n01_08

Giallombardo, R. (1966). Society of women. New York: John Wiley \& Sons, Inc.

Glaser, B. \& Strauss, A. L. (1967). The discovery of grounded theory: Strategies for qualitative research. Chicago: Aldine Publishing Company.

Graffam, J., Shinkfield, A., \& Hardcastle, L. (2008). The perceived employability of exprisoners and offenders. International Journal of Offender Therapy and Comparative Criminology, 52, 673-685. doi:10.1177/0306624X07307783

Greer, K. (2000). The changing nature of interpersonal relationships in a women's prison. The Prison Journal, 80 (4), 442-468. doi: 10.1177/0032885500080004009

Hammett, T., Harmon, P., \& Maruschak (1999). 1996-1997 update: HIV/AIDS, STDs, and TB in correctional facilities. Washington, DC: National Institute of Justice. Retrieved from: https://www.ncjrs.gov/pdffiles1/176344.pdf

Hepburn, J., \& Griffin, M. (2004). The effect of social bonds on successful adjustment to probation: An event history analysis. Criminal Justice Review, 29, 46-75. doi: $10.1177 / 073401680402900105$

Hindelang, M. (1973). Causes of delinquency: A partial replication and extension. Social Problems, 20, 471-487. http://dx.doi.org/10.2307/799709

Hirschi, T. (1969). Causes of Delinquency. Berkley: University of California Press.

Hochstetler, A., DeLisi, M., \& Pratt, T. C. (2010). Social support and feelings of hostility among released inmates. Crime and Delinquency, 56 (4), 588-607. 
doi:10.1177/0011128708319926

Hoffman, H. C., \& Dickinson, G. E. (2011). Characteristics of Prison Hospice Program in the United States. American Journal of Hospice \& Palliative Medicine, 28 (4), 245-252. doi: $10.1177 / 1078345815588842$

Huggins, D., Capeheart, L. \& Newman, E. (2006). Deviants or scapegoats. The Prison Journal, 86 (1), 114-139. doi: 10.1177/0032885505284702

Huebner, B. M. (2007). Racial and ethnic differences in the likelihood of marriage: The effect of incarceration. Justice Quarterly, 24, 156-183. http://dx.doi.org/10.1080/07418820701201073

Human Rights Watch. (2004). No second chance: People with criminal records denied access to public housing. New York: Human Rights Watch. Retrieved from: http://www.hrw.org/sites/default/files/reports/usa1104.pdf

Intravia, J., Jones, S., \& Piquero, A. R. (2012). The roles of social bonds, personality and perceived costs: An empirical investigation into Hirschi's "new" control theory. International Journal of Offender Therapy and Comparative Criminology, 56 (8), 1182-1200. doi: 10.1177/0022427801038002001

Irwin, J., \& Cressey, D. (1962). Thieves, convicts, and the inmate culture. Social Problems, 10 (2), 142-155. http://dx.doi.org/10.2307/799047

Jasperson, R. A. (2010). Animal-assisted therapy with female inmates with mental illness: A case example from a pilot program. Journal of Offender Rehabilitation, 49, 417-433. http://dx.doi.org/10.1080/10509674.2010.499056

Jiang, S. \& Winfree Jr., L. (2006). Social support, gender, and inmate adjustment to prison life. The Prison Journal, 86 (1), 32-55. doi: 10.1177/0032885505283876

Jones, R. (1993). Coping with separation: Adaptive responses of women prisoners. Women and Criminal justice, 5 (1), 71-97. http://dx.doi.org/10.1300/J012v05n01_04

Keaveny, M. E., \& Zauszniewski, J. A. (1999). Life events and psychological well-being in women sentenced to prison, Issues in Mental Health Nursing, 20 73-89.

http://dx.doi.org/10.1080/016128499248790

Keeton, K., \& Swanson, C. (1998). HIV/AIDS education needs assessment: A comparative study of jail and prison inmates in NorthWest Florida. The Prison Journal, 78 (2), 119-132. doi: $10.1177 / 003288559807800200$.

Koons, B., Burrow, J., Morash, M., \& Bynum, T. (1997). Expert and offender perceptions of program elements linked to successful outcomes for incarcerated women. Crime and Delinquency, 43 (4), 512-532. doi: 10.1177/0011128797043004007

Lasley, J. (1998). Toward a control theory of white-collar offending. Journal of Quantitative Criminology, 4 (4), 347-362. doi: 10.1007/BF01065344

Laub, J., \& Sampson, R. (2003). Shared beginnings, divergent lives: Delinquent boys to age 7. MA: Harvard University Press.

LeBel, T. (2012). Invisible stripes: Formerly incarcerated persons' perception of stigma. Deviant Behavior, 33, 89-107. http://dx.doi.org/10.1080/01639625.2010.538365

Li, S., \& MacKenzie, N. (2003). The gendered effects of adult social bonds on the criminal 
activities of probationers. Criminal Justice Review, 28, 278-298.

doi: $10.1177 / 073401680302800205$.

Linden, R. \& Perry, L. (1983). The effectiveness of prison education programs. Journal of Offender Counseling, Services \& Rehabilitation, 6 (4), 43-57.

http://dx.doi.org/10.1300/J264v06n04_04.

Lofland, J. (1969). Deviance and Identity. New Jersey: Prentice Hall.

Lopoo, L. M., \& Western, B. (2005). Incarceration and the formation and stability of marital unions. Journal of Marriage and Family, 67, 721-734. doi: 10.1111/j.1741-

3737.2005.00165.x

Mackenzie, D. L., De Li, S. (2002). The impact of formal and informal social controls on the criminal activities of probationers. Journal of Research in Crime and Delinquency, 39, 243276. doi: $10.1177 / 002242780203900301$

Maruna, S. (2001). Making good: How exconvicts reform and reclaim their lives. Washington, D.C.: American Psychological Association.

Maruna, S., \& LeBel, T. P. (2003). Welcome home? Examining the reentry court concept from a strengths-based perspective. Western Criminology Review, 4, 91-107. Retrieved from: http://westerncriminology.org/documents/WCR/v04n2/article_pdfs/marunalebel.pdf

Maruschak, L. M. (2015). HIV in prisons: 2001 to 2010. Washington DC: U.S. Department of Justice. Retrieved from: http://www.bjs.gov/content/pub/pdf/hivp10.pdf

Moyer, I. (1984). Deceptions and realities of life in women's prisons. The Prison Journal, 64, 45-56. doi: 10.1177/003288558406400105

Nouwen, H. (1972). The wounded healer. New York: Doubleday.

O'Connell, D. J. (2003). Investigating latent trait and life course theories as predictors of recidivism among an offender sample. Journal of Criminal Justice, 31, 455-467.

http://dx.doi.org/10.1016/S0047-2352(03)00050-3

Petersilia, J. (2006). Understanding California corrections. Irvine, CA: UC Irvine Center for

Evidence Based Corrections. Retrieved from:

http://www.prisonpolicy.org/scans/carc/understand_ca_corrections.pdf

Petersilia, J. (2003). When prisoners come home: Parole and prisoner reentry. NY: Oxford University press.

Piquero, N. (2003). A recidivism analysis of Maryland's community probation program. Journal of Criminal Justice, 31, 295-307. http://dx.doi.org/10.1016/S0047-2352(03)00024-2

Pollock-Byrne, J. (1990). Women, Prison \& Crime. California: Brooks/Cole Publishing Company.

Proctor, J. (2009). The Imprisonment Insights of Female Inmates: Identity \& Cognitive Shifts for Exiting a Criminal Lifestyle. Justice Policy Journal, 6 (1), 1-32. Retrieved from: http://www.cjcj.org/uploads/cjcj/documents/the_imprisonment.pdf

Propper, A. (1982). Make-believe families and homosexuality among imprisoned girls. Criminology, 20 (1), 127-138. doi: 10.1111/j.1745-9125.1982.tb00452.x

Rankin, J. (1976). Investigating the interrelations among social control variables and 
conformity. Journal of Criminal Law and Criminology, 67 (4), 740-480. Retrieved from: http://scholarlycommons.law.northwestern.edu/cgi/viewcontent.cgi?article $=6002 \&$ context $=$ jclc Reisig, M., Holtfreter, K., \& Morash, M. (2002). Social capital among women offenders: Examining the distribution of social networks and resources. Journal of Contemporary Criminal Justice, 18 (2), 167-187. doi: 10.1177/1043986202018002004

Richie, B. (2001). Challenges incarcerated women face as they return to their communities: Findings from life history interviews. Crime and Delinquency, 47 (3), 368-389. doi: $10.1177 / 0011128701047003005$

Rocque, M., Bierie, D. M., Posick, C., \& MacKenzie, D. L. (2013). Unraveling change: Social bonds and recidivism among released offenders. Victims and Offenders, 8, 209-230. http://dx.doi.org/10.1080/15564886.2012.755141

Rosenbaum, J. (1987). Social control, gender, and delinquency: An analysis of drug, property and violent offenders. Justice Quarterly, 4 (1), 117-132. http://dx.doi.org/10.1080/07418828700089221

Sampson, R., \& Laub, J. (1993). Crime in the Making. Massachussetts: Harvard University Press.

Sampson, R., \& Laub, J. (1990). Crime and deviance over the life course: The salience of adult social bonds. American Sociological Review, 55 (5), 609-627. Retrieved from:

http://faculty.washington.edu/matsueda/courses/517/Readings/Sampson\%20Laub\%20Lifecourse .pdf

Sampson, R., Laub, J., \& Wimer, C. (2006). Does marriage reduce crime? A counterfactual approach to within individual casual effects. Criminology, 44, 465-508. doi: 10.1111/j.17459125.2006.00055.x

Sepsi, V. (1974). Girl recidivists. Journal of Research in Crime and Delinquency, 11 (1), 70 79. doi: $10.1177 / 002242787401100109$

Severance, T. (2005). You know who you can go to: Cooperation and exchange between incarcerated women. The Prison Journal, 85 (3), 343-367. doi: 10.1177/0032885505279522

Shover, N., Norland, S., James, J., \& Thornton, W. (1979). Gender roles and Delinquency. Social Forces, 58 (1), 162-175. doi: 10.1093/sf/58.1.162

Shinkfield, A., \& Graffam, J. (2009). Community reintegration of ex-prisoners: Type and degree of change in variables influencing successful reintegration. International Journal of Offender Therapy and Comparative Criminology, 53, 29-42. doi:10.1177/0306624X07309757

Smart, C. (1976). Women, crime, and criminology: A feminist critique. London: Routledge \& Kegan Paul Ltd.

Sommers, I., Baskin, D., \& Fagan, J. (1994). Getting out of the life: Crime desistance by female street offenders. Deviant Behavior, 15 (2), 125-149. http://dx.doi.org/10.1080/01639625.1994.9967964.

Sutherland, E. (1949). White Collar Crime. New York: Holt, Rinehart \& Winston.

Terry, K. J., \& Freilich, J. D. (2012). Understanding child sexual abuse by Catholic priests from a situational perspective, Journal of Child Sexual Abuse, 21 (4), 437-455. 
http://dx.doi.org/10.1080/10538712.2012.693579

Thigpen, M. L., \& Hunter, S. M. (1998). Hospice and palliative care in prisons. Colorado:

U.S. Department of Justice. Retrieved from: http://static.nicic.gov/Library/014785.pdf

Thompson, M. \& Petrovic, M. (2009). Gendered Transitions. Journal of Research in

Crime and Delinquency, 46 (3), 377-408. doi: 10.1177/0022427809335172

Tripodi, S. (2010). The influence of social bonds on recidivism: A study of Texas male prisoners. Victims \& Offenders, 5, 354-370. http://dx.doi.org/10.1080/15564886.2010.509660

Toch, H. (1975). Men in crisis. Human breakdowns in prison. New Jersey: Transaction Publishers.

Uggen, C. (2000). Work as a turning point in the life course of criminals: A duration model of age, employment, and recidivism. American Sociological Review, 65, 529-546. Retrieved from: http://users.cla.umn.edu/ uggen/Uggen_asr_00.pdf

Valera, P., Chang, Y., Hernandez, D., \& Cooper, J. (2015). Exploring kinship and social support in women with criminal justice backgrounds. Journal of Offender Rehabilitation, 54, 278-295. http://dx.doi.org/10.1080/10509674.2015.1025178

Western, B. (2002). The impact of incarceration on wage mobility and inequality. American Sociological Review, 67, 526-546. doi: 10.2307/3088944

Wright, J. P., \& Cullen, F. T. (2004). Employment, peers and life-course transitions. Justice Quarterly, 21 (1), 183-205. http://dx.doi.org/10.1080/07418820400095781

Wright, E. M., Salisbury, E. J., \& Van Voorhis, P. (2007). Predicting the prison misconducts of women offenders. The Journal of Contemporary Criminal Justice, 23 (4), 310-340. doi: $10.1177 / 1043986207309595$

Wyse, J. B., Harding, D. J., \& Morenoff, J. D. (2014). Romantic relationships and criminal desistance: Pathway and Processes. Sociological Forum, 29 (2), 365-385.

doi: $10.1111 /$ socf. 12088

Kimberly Collica-Cox, Ph.D., is an associate professor with Pace University. She writes and presents on issues regarding female inmates, rehabilitation, reintegration, and prison-based peer programming. She trains in the area of HIV and incarceration. A former corrections practitioner, she is a certified ACA and PREA auditor. 